\title{
PENDIDIKAN ISLAM DAN HAK PE- NYANDANG DISABILITAS; SUATU PANDANGAN KOMPREHENSIF DAN INTEGRATIF
}

\author{
Oleh: \\ Ukhtul Iffah \\ Hasanah \\ Baitur Rahman \\ Email: \\ Universitas Ibrahimy \\ Universitas Ibrahimy
}

uunkwaheed@gmail.com

hasanahthahir2@gmail.com

baiturrahman.stitjembrana@gmail.com

STIT (Sekolah Tinggi Ilmu

Tarbiyah) Jembrana Bali

\begin{abstract}
:
Education is an effort made consciously and systematically to empowering all of the potential students to become complete human beings. the implication of education for society is being independent. therefore education is too important on the side of the community and it is increasingly difficult to leave it. independent society is a society that can supply all of their life necessities without depend on whatever. a lot of literature discusses moral decadention, so that necessary to socialize Islamic education massively to minimize moral decadention. on the other aspect, education is right of humans, including children with special needs. people with disabilities should not be underestimated by everyone, in Islamic religion never discriminate buman existence based on physically, psychically, tradition, and other aspects except submission to Allah SWT.
\end{abstract}

Keywords: Islamic Education, Disability Rights

\section{LATAR BELAKANG}

Pada revolusi industri 4.0 saat ini, pendidikan bukanlah suatu hal yang naif lagi bagi masyarakat dunia (world society). Sebuah zaman yang telah penuh dengan teknologi-teknologi super canggih, menjadikan segala informasi yang penting menjadi mudah didapat. Manusia tidak perlu lama menunggu informasi atau berita tertentu yang diinginkannya. Hanya memerlukan beberapa menit bahkan detik sekalipun. Hadirnya teknologi tersebut juga menciptakan sebuah kondisi tanpa batas didunia ini, karena manusia bisa berinteraksi, mengetahui dan merasakan apa yang terjadi pada orang atau saudaranya yang berada di Negara nun jauh seberang sana. Semakin praktis dan dinamisnya kehidupan masyarakat pada saat ini, melatarbelakangi perkembangan pengetahuan yang berakibat pada kemajuan teknologi yang terus menerus diperbaharukan oleh kalangan pelajar, peneliti, dan khalayak umum. Salah satu media yang paling baik dalam mengakomodasi perkembangan pengetahuan dan berpikir kritis adalah pendidikan. Sebagaimana dilandasi oleh statement Siti Murtiningsih bahwa karena pendidikan masyarakat menjadi maju, begitu pula pendidikan yang maju hanya dapat dijumpai dalam masyarakat yang maju. ${ }^{1}$

Oleh karena itu, pendidikan sudah menjadi kebutuhan tersendiri bagi masyarakat dalam merubah dunia dan meningkatkan kualitas dirinya. Sehingga pendidikan menurut Plato menjadi kewajiban tersendiri bagi negara untuk menyelenggarakannya. ${ }^{2}$ Dengan tujuan negara tersebut bisa menjadi sebuah negara yang maju, dengan memiliki masyarakat yang makmur dan sejahtera dalam segala aspek kehidupannya. Sehingga terbentuklah tatanan masyarakat yang intelek dan cerdas dalam membangun negaranya.

Kesadaran peserta didik untuk berpikir kritis dan secara kreatif mengembangkan potensi dirinya sebagai subyek pengetahuan sangatlah penting diterapkan oleh guru. Sehingga pada nantinya

\footnotetext{
${ }^{1}$ Siti Murtiningsih, Pendidikan Sebagai Alat Perlawanan: Teori Pendidikan Radikal Paulo Freire, (Yogyakarta: Resist Book, 2004), 11.

2 Jalaluddin dan Abdullah Idi, Filsafat Pendidikan: Manusia, Filsafat dan Pendidikan, (Depok: Raja Grafindo Persada, 2016), 72.
} 
dapat tercipta pula pribadi yang tanggap mengubah dunianya. Tidak hanya sekedar menjadi pribadi yang "ada" di dunia, melainkan dapat bersama dunia. ${ }^{3}$ Sebagaimana yang telah dikatakan oleh Ki Hajar Dewantara bahwa pendidikan harus mampu memajukan budi pekerti (batin dan karakter), pikiran dan tumbuh anak. ${ }^{4}$

Upaya dalam menumbuhkan dan memajukan budi pekerti, pikiran dan tumbuh anak tersebut dapat tercapai melalui penanaman nilai-nilai karakter, salah satunya menggunakan pendekatan pendidikan Islam. Karakter merupakan tujuan pokok dari pendidikan Islam itu sendiri, sebab pada dasarnya, Abuddin Nata menjelaskan bahwa tujuan akhir pendidikan Islam ialah berada pada rasa penghambaan secara totalitas kepada Allah SW'T baik individu, kelompok atau masyarakat luas. ${ }^{5}$ Selain itu sumber utama pendidikan Islam senantiasa merujuk pada nash-nash Alquran, sunnah, ijma' dan qiyas. Tentu implikasi dari sumber-sumber pendidikan Islam tersebut adalah pandangan Islam yang universal dan menghormati akan perbedaan latar belakang atau pun kasta setiap insan. Setiap manusia memiliki kedudukan yang egaliter tanpa pandang bulu ataupun pilih kasih, hal ini sangat sesuai dalam prinsip pendidikan bahwa tidak adanya pilih kasih dalam memberikan bimbingan kepada peserta didik.

Memajukan dan menumbuhkan budi pekerti, pikiran dan tumbuh anak juga bisa diupayakan melalui sinergitas yang kokoh dalam praktik tripusat pendidikan atau yang kerap disebut juga sebagai trisentra pendidikan, dalam hal ini dikemukakan oleh Ki Hajar Dewantara pada tahun 1935. Adapun mengenai tripusat pendidikan yaitu keluarga, sekolah dan gerakan kepemudaan. Menurutnya masingmasing pusat pendidikan tersebut mempunyai tujuan yang khas, namun tetap berkorelasi satu sama lain. ${ }^{6}$

Poin penting dari hal tersebut di atas adalah menjadikan peserta didik yang susila dan warga

\footnotetext{
3 Jalaluddin dan Abdullah Idi, Filsafat Pendidikan: Manusia, Filsafat dan Pendidikan, (Depok: Raja Grafindo Persada, 2016), 12.

${ }^{4}$ Ki Hajar Dewantara, Bagian Pertama Pendidikan, (Yogyakarta: Yayasan Persatuan Taman Siswa, 2011), 14.

5 Abuddin Nata, Ilmu Pendidikan Islam, (Jakarta: Prenadamedia Group, 2010), 62.

${ }^{6}$ H.A.R. Tilaar, Pedagogik Teoritis Untuk Indonesia, (Jakarta: Kompas, 2015), 15.
}

negara yang demokratis serta bertanggung jawab atas kesejahteraan masyarakat dan tanah air. Hal ini sesuai dengan apa yang telah diamanatkan oleh UndangUndang No 4 Tahun 1950 dalam pasal 4 tentang tujuan pendidikan. ${ }^{7}$ Jika demikian pendidikan juga memiliki tujuan dalam kehidupan dan penghidupan rakyat. ${ }^{8}$ Dalam rangka mencapai kesejahteraan yang hakiki.

Eksistensi pendidikan dalam menyiapkan kader-kader yang siap mengawal kesejahteraan bangsanya dan negaranya tersebut, perlu ada bimbingan khusus terhadap murid yang diberikan oleh guru dalam lingkungan sekolah, masyarakat dalam lingkungan social dan orang tua dalam lingkungan keluarga. Sesuai dengan arti pendidikan (paedagogik) yang berasal dari bahasa Yunani, yaitu paedos berarti anak dan ago berarti memimpin atau membimbing. Jadi, pedagogic secara etimologis berarti membimbing anak. '9 Selain dari itu, pendidikan juga bertugas dalam menuntun proses perkembangan anak. $^{10}$

Dalam proses membimbing dan menuntun perkembangan anak, maka perlu adanya pengetahuan khusus mengenai anak. Semisal perkembangan anak, kondisi fisiologis dan psikisnya, serta usaha-usaha atau upaya-upaya dalam membimbingnya. Karena setiap anak memiliki perbedaan mendasar yang tidak dapat dipungkiri keberadaannya. ${ }^{11}$ Dalam artian, hal tersebut sudah menjadi suatu kealamian (natural) yang terdapat pada pribadi anak. Dalam perkembangannya ada anak yang sehat dan adapula anak yang kurang sehat. Ada anak yang mempunyai kelebihan cepat tanggap dalam memahami materi, ada pula anak yang susah atau lamban dalam memahami materi yang menjadi topic bahasan. Ada anak yang mampu melihat dan mendengar dengan sempurna, ada pula anak yang memiliki keterbatasan dalam melihat dan mendengar atau cacat. Hal ini merupakan masalah

H.A.R. Tilaar, Pedagogik Teoritis Untuk Indonesia, Jakarta: Kompas, 2015), 105.

${ }^{8}$ Ki Hajar Dewantara, Bagian Pertama Pendidikan, (Yogyakarta: Yayasan Persatuan Taman Siswa, 2011), 14.

${ }^{9}$ H.A.R. Tilaar, Pedagogik Teoritis Untuk Indonesia, (Jakarta: Kompas, 2015), 10.

${ }^{10}$ Moh. Nawafil, Cornerstone Of Education: Landasan-Landasan Pendidikan, (Yogyakarta: Absolut Media, 2018), 9-10.

${ }^{11}$ Moh. Nawafil dan Junaidi, "Revitalisasi Paradigma Baru Dunia Pembelajaran yang Membaskan", Jurnal Pendidikan Islam Indonesia, vol. 4, No. 2, (April, 2020), 217-218. 
yang penting dalam ranah pendidikan yang harus diketahui bersama oleh pendidik atau calon pendidik, khususnya dalam ranah bimbingan pendidikan Islam. Oleh karena itu sangatlah penting dalam menjawab dan mengulas secara eksplisit mengenai keterbatasan anak atau yang sering disebut juga sebagai disabilities, cbildren special needs dan kaitannya serta prinsip-prinsip dalam bimbingan pendidikan Islam.

\section{PEMBAHASAN}

\section{Landasan-Landasan Pendidikan}

Dalam bahasa Indonesia, kata landasan memiliki banyak arti, baik itu yang sama atau serupa dengan kata-kata yang terkait lainnya. Dalam Kamus Besar Bahasa Indonesia, kata landasan awalnya dari kata dasar landas yaitu alas, tumpuan. Pada segi benua kata landasan adalah bagian dasar laut yang paling tepi, relief dasar laut yang menurun perlahan-lahan mulai dari arah pantai kearah tengah lautan sampai kepinggir, tempat dasar laut tiba-tiba menurun, paparan benua. Jadi, kata dasar laut yang paling tepi dan paparan benua adalah sebagai kata kunci yang paling tepat untuk memahami kata landas dalam sudut pandang benua.

Selain benua, kata landas juga bisa berarti sebagai data dan kontinen. Data adalah suatu kenyataan yang benar dan nyata yang dapat dijadikan dasar kajian (analisis atan kesimpulan). Namun data yang seperti itu lebih familiar dengan arti berkas komputer yang dapat digunakan untuk pengolahan data, juga bisa berarti sebagai dasar dari data-data komputer awal untuk mengelola data selanjutnya. Adapun konklusinya tetap berada pada kata dasar sebagai kunci untuk memahami secara tepat dan mudah sehingga dapat membantu akan suatu hal yang diinginkan.

Kontinen adalah salah satu dari lima atau enam daratan yang luas pada bola dunia atau sering juga disebut sebagai benua (Asia, Eropa, Afrika, Amerika, Australia). Jadi kata kontinen yang menjadi arti dari kata landas adalah landas benua atau paparan benua. Sebagaimana yang telah kita ketahui bahwa hal yang paling pokok dalam proses kehidupan manusia di muka bumi ini salah satunya ialah pasti membutuhkan yang namanya daratan untuk beradaptasi, beranakpinak, dan merasakan keamanan serta kenyamanan. Karena manusia bukanlah makhluk yang dapat hidup secara alamiah di dua alam yang berbeda.
Lain halnya dengan kata landasan sebagaimana lazimnya, kata landsan mempunyai arti independent yang tidak jauh berbeda dengan kata dasarnya, yaitu sebagai alas, bantalan, paron (alas untuk. menempa, terbuat dari besi), lapangan terbang, dasar atau tumpuan. Oleh karena itu, yang paling esensial dari kata landasan tersebut adalah dasar atau tumpuan yang menjadi dasar pijakan sesuatu. Apabila diklasifikasikan kata landsan tersebut terbagi menjadi dua kategori, yang pertama bersifat material, contohnya seperti landasan pesawat terbang yang tendensinya lebih spesifik terhadap materi. Kedua, bersifat konseptual, contohnya sebagai landasan konseptual, berupa konsep. Landsan ini, biasanya memiliki tendensi yang identik dengan asumsiasumsi. Adapun asumsi terdidri dari tiga golongan yaitu aksioma, postulat dan premis tersembunyi.

Dalam bahasa Inggris, kosa kata dasar merupakan terjemahan dari kosa kata fundation atau fundament, yang berarti landasan atau dasar. ${ }^{12}$ Dan dalam bahasa Arab, kosa kata landasan merupakan terjemahan dari kata asas yang jamaknya ialah usus, bermakna fundation (dasar atau landasan), fundament (landasan), groundwork (landasan kerja), ground (terowongan), basis (dasar), dan keynote (catatan kunci). ${ }^{13}$

Maka dari beberapa pengertian di atas dapat dipahami bersama bahwa kata landasan merupakan segala aktivitas, tindakan, atau pekerjaan yang bersifat fisik maupun non fisik, yang pada intinya merupakan sesuatu yang berada di paling bawah. Jika dilihat dari fungsinya memiliki arti paling utama, penting, dan pokok yang pada akhirnya diharapkan untuk bisa menopang sebuah pekerjaan atau kegiatan tersebut agar lebih kuat dan kokoh.

Seperti yang telah banyak dijelaskan dalam beberapa buku pendidikan bahwa sistem pendidikan memiliki beberapa aspek, visi, misi, kurikulum, bahan ajar, proses belajar, alat pendidikan, pendidik, peserta didik, lingkungan, fasilitas, biaya dan lain sebagainya.

\footnotetext{
${ }^{12}$ John M. Echols dan Hassan shadily, Kamus Inggris Indonesia, (Jakarta: PT Gramedia dan Ithaca London : Cornell University Press, 2003), 35.

${ }^{13}$ Hans Wehr, A Dictionary of Modern Written Arabic, (Beirut: Librarie Du Liban and London: Macdonald and Evans LTD, 1974), 15.
} 
Berbagai komponen pendidikan tersebut nantinya akan membentuk sebuah konstruksi bangunan pendidikan yang kokoh. Sudah tentu pasti, supaya konstruksi bangunan itu kokoh maka harus memiliki dasar atau landasan yang kuat untuk menopang dan menyanggah sebuah bangunan tersebut agar berdiri tegak serta dapat dijadikan bahan acuan dalam praktik pendidikan kedepannya. Secara garis besar pendidikan dapat dipahami dari dua sudut pandang, yang pertama adalah education as practice yakni pendidikan sebagai praktek. Sehingga sering kita dengar istilah praktek pendidikan. Kedua adalah education as study yakni pendidikan sebagai studi. Oleh karenanya sering kita dengar juga istilah studi pendidikan.

Praktek pendidikan adalah suatu aktivitas atau kegiatan seseorang maupun kelompok, institusi, yang membimbing, membangun, mengarahkan seseorang yang lain dalam mencapai tujuan-tujuan pendidikan. Adapun kegiatan bantuan dalam praktek pendidikan berupa pengelolaan pendidikan dan praktek pendidikan itu sendiri. Pengelolaan pendidikan biasanya identik dengan pengelolaan dan mengatur segala hal yang berkaitan dengan pendidikan baik itu yang berupa makro atau pun mikro. Sedangkan studi pendidikan adalah suatu usaha seseorang maupun sekelompok orang yang bertujuan untuk memahami pendidikan.

Kajian tentang dasar pendidikan telah banyak didiskusikan dan diperbincangkan secara hangat oleh para ahli. Salah satunya Abdul Mujib dan Yusuf Mudzakir berpendapat bahwa dasar pendidikan Islam adalah landasan operasional yang dijadikan untuk merealisasikan dasar ideal atau sumber pendidikan Islam. ${ }^{14}$ selain itu Abuddin Nata juga turut berpendapat mengenai landasan pendidikan ini, menurut beliau landasan pendidikan bukan hanya sebuah landsan operasional saja akan tetapi lebih merupakan landsasan konseptual. Karena menurut beliau landasan pendidikan tidak secara langsung hanya memberikan dasar terhadap pendidikan saja, akan tetapi lebih memberikan dasar bagi penyusunan konsep pendidikan.

Dalam menyebutkan macam-macam landasan pendidikan ini, para tokoh pendidikan

\footnotetext{
${ }^{14}$ Abdul Mujib dan Jusuf Mudzakir, Imu Pendidikan Islam, (Jakarta: Kencana Prenada Media, 2006), 14.
}

mempunyai multi interpretasi yang sangat bervariasi. Salah satunya Hasan Langgulung, menyebutkan bahwa macam-macam landasan pendidikan ada enam macam, yaitu historis, filosofis, ekonomis, sosiologis, psikologis, politis. ${ }^{15}$ Akan tetapi, pernyataan Hasan Langgulung ini mendapat kritikan yang berarti dari Yusuf Mudzakir, karena menurut beliau pernyataan Hasan Langgulung ini dianggap terlalu sekuler. Mengapa demikian? Karena Hasan Langgulung menempatkan filsafat pada posisi central, dan tidak memasukkan dasar religius di dalamnya, ditambah ia menjadikan filsafat sebagai induk dari segala dasar. Sedangkan menurut Abdul Mujib dan Yusuf Mudzakir segala hal yang menjadi dasar bagi segala sesuatu ialah agama. Agama menjadi dasar operasional sesuatu, sebab agama menjadi frame bagi setiap aktivitas yang dijalani, agar lebih berwarna, bervariasi, mempunyai tujuan jelas, bermakna, dan bersifat ubudiyah. Maka dari itu perlunya menambahkan dan mengikut sertakan dasar agama dalam macammacam landsan pendidikan. ${ }^{16}$

Secara garis besar Abuddin Nata, membagi macam-macam landasan pendidikan tersebut menjadi tiga bagian. Pertama adalah landasan agama, yang kedua adalah landasan filsafat, dan yang ketiga adalah landasan ilmu pengetahuan. Karena antara agama, filsafat dan ilmu pengetahuan memiliki differensiasi, maka perlu di spesifikasi lagi sehingga menjadi jelas dan terarah. Secara epistimoligis dan ontologis ilmu pengetahuan merupakan rasionalisasi dan sistematisasi terhadap berbagai fenomena dan sesuatu yang dilihat, diamati, dan dicatat. Jika sesuatu yang dilihat, diamati, dicatat adalah fenomena-fenomena sosial, maka akan membentuk suatu rumpun ilmu sosial. Sebaliknya, jika yang dilihat, diamati, dan dicatat adalah fenomena-fenomena alam, maka akan membentuk suatu rumpun ilmu-ilmu alam (natural sains).

Adapun filsafat ialah konsep-konsep tentang hakikat atau inti dari segala sesuatu yang dihasilkan dengan cara berpikir secara mendalam, spekulatif, sistematik, radic, dan universal. Dalam filsafat yang paling ditekankan adalah mencari kebenaran yang

\footnotetext{
${ }^{15}$ Hasan Langgulung, Asas-Asas Pendidikan Islam, Jakarta: PT Al-Husana, 1988), 6-12

${ }^{16}$ Abdul Mujib dan Jusuf Mudzakir, Imu Pendidikan Islam, (Jakarta: Kencana Prenada Media, 2006), 44.
} 
sesungguhnya atau sejati. Biasanya juga sering dikataka bahwa filsafat adalah bubbul bikmah (cinta akan kebenaran). Mengenai agama, jika dilihat dari segi sumbernya maka mutlak datangnya dari tuhan yaitu Allah. Namun jika dilihat dari apa yang dipraktekkan dan dipahami oleh manusia dalam kehidupan sehari-harinya, termasuk juga agama, maka interpretasinya adalah ilmu yang dihasilkan melalui ijtihad manusia yang menghasilkan ilmu agama.

Secara aksiologis, agama, filsafat dan ilmu pengetahuan tergantung atas siapa yang akan menggunakannya. Jika yang menggunakan ketiganya itu adalah orang yang baik-baik maka hasilnya pun juga akan baik. sebaliknya jika yang menggunakan ketiga ilmu tersebut adalah orang yang jahat atau tidak baik maka hasilnya pun juga akan tidak baik atau buruk. ${ }^{17}$

Maka dari itu, memahami eksistensi landasanlandasan pendidikan terutama yang terintegrasi antara agama, filsafat dan ilmu pengetahuan, begitu vital guna melestarikan nilai-nilai religius berbingkai pendidikan Islam sebagai basis pengembangan pohon keilmuan.

\section{Pendidikan Islam}

Dalam beberapa literasi pendidikan, banyak yang menyebutkan bahwa pendidikan Islam sering diartikan dengan at-tarbiyah, at-ta'lim dan at-ta'dib. Jika ditelisik pada Mu'jam al-Lughah al-Arabiyah al-Mu'ashirah (A Dictionary of Modern Written Arabic) karangan Hans Wehr, kata at-tarbiyah diartikan sebagai education (pendidikan), upbringing (pengembangan), teaching (pengajaran), instruction (perintah), pedagogy (pembinaan kepribadian), breeding (memberi makan), raising (menumbuhkan). ${ }^{18}$ Kata at-tarbiyah berasal dari kata rabba, yarubbu, rabban yang berarti mengasuh (anak), memimpin. ${ }^{19}$ Berarti makna dari kata at-tarbiyah adalah menumbuh kembangkan segala segala potensi diri peserta didik, baik secara physical, psychological, social, maupun spiritual. Pada kata at-tarbiyah juga mengandung cakupan tujuan pendidikan yaitu menumbuhkan dan mengembangkan potensi dan

\footnotetext{
${ }^{17}$ Abuddin Nata, Ilmu Pendidikan Islam, (Jakarta: Prenadamedia Group, 2010), 91.

${ }^{18}$ Abuddin Nata, Ilmu Pendidikan Islam, Jakarta: Kencana, 2010), 7 .

${ }^{19}$ Mahmud Yunus, Kamus Arab-Indonesia, (Jakarta: PT Hidakarya Agung, t.t), 136.
}

proses pendidikan yaitu memelihara, mengasuh, merawat, memperbaiki dan mengaturnya. ${ }^{20}$

Setelah kata at-tarbiyah juga terdapat kata at-ta'lim yaitu dapat bermakna sebagai information (informasi), advice (nasihat), direction (pengarahan), teaching (pengajaran), training (pelatihan), schooling (pembelajaran). ${ }^{21}$ Mahmud Yunus memberikan definisi pada kata at-ta'lim secara singkat ialah berkenaan pada hal teacbing dan training. ${ }^{22}$ Namun demikian para tokoh pendidikan banyak menyebutkan atau mendefinisikan at-ta'lim sebagai pengajaran. Sedangkan at-tarbiyah diartikan sebagai pendidikan.

Selanjutnya ada kata at-ta'dib berasal dari kata adaba, yuaddibu, ta'diban yang dapat berarti education (pendidikan), discipline (disiplin, patuh dan tunduk pada aturan), punisment (peringatan atau hukuman), dan chastisement (hukuman atau penyucian). Kata at-ta'dib berasal dari kata adab yang berarti beradab, bersopan santun dan bertatakrama, budi pekerti, akhlak, moral dan etika. ${ }^{23}$ Hasan Langgulung menakar definisi pendidikan pada sebuah usaha mempersiapkan peserta didik agar mampu menemukan posisi yang sesuai dengan potensinya, mentransformasikan ilmu dan Islamic value yang berkolerasi dengan fungsi umat insan dalam rangka menuai pundi-pundi amal ibadah di dunia dan dapat bermanfaat di akhirat. Adapun Ahmad D. Marimba mendefinisikan pendidikan Islam sebagai sebuah bimbingan kepada peserta didik yang mencakup ranah jasmaniyah dan robaniyah dengan berlandaskan pada sumber legalitas Islam guna membentuk keperibadian luhur menurut pandangan Islam.

Oleh demikian, berdasarkan pengertian pendidikan Islam secara bahasa dan statement ahli pendidikan yang dijelaskan sebelumnya bahwa esensi dari pendidikan Islam ialah pada sebuah bimbingan fisiologis dan psikologis peserta didik untuk mempersiapkan kematangan dirinya guna menemukan potensi terbaik dan keperibadian luhur.

\footnotetext{
${ }^{20}$ Abuddin Nata, Ilmu Pendidikan Islam, Jakarta: Kencana, 2010), 8 .

${ }^{21}$ John M. Echols dan Hassan shadily, Kamus Inggris Indonesia, Jakarta: PT Gramedia dan Ithaca London : Cornell University Press, 2003), 35.

${ }^{22}$ Mahmud Yunus, Kamus Arab-Indonesia, Jakarta: PT Hidakarya Agung, t.t), 278.

${ }^{23}$ Abdul Majid dan Yusuf Mudzakir, Ilmu Pendidikan Islam, (Jakarta: Prenada Media, 2006), 20.
} 
Bimbingan yang diberikan oleh seorang pendidik haruslah berpedoman pada sumber pendidikan Islam yaitu Alquran, sunnah, ijma' dan qiyas serta memberlakukan peserta didik secara egaliter sebagai manusia paripurna atas segala kompleksitas hakhaknya. Pendidik, sejatinya diutamakan membimbing peserta didik agar memiliki ketakwaan kepada Tuhan Yang Maha Esa sebab jika ditinjau dari sektor tujuan pendidikan Islam adalah penghambaan secara totalitas kepada Allah SWT di level individu, kelompok dan mayarakat luas.

\section{Disabilitas dalam Pandangan Islam}

Dalam agama Islam, hakikat kedudukan manusia di pandang secara egaliter. Apapun latar belakang sesosok manusia, baik itu dari aspek ras, budaya, adat bahkan negara atau wilayah di hadapan Allah SW'T tetaplah sama. Hal yang dapat membedakan kedudukan manusia di sisi Allah SW'T adalah ibadahnya dan amal shaleh yang dikerjakan di dunia. Oleh karena itu menjaga hati senantiasa bersih dari kotoran-kotoran yang dapat membawa diri jauh dari Allah SW'T sangatlah penting dalam kehidupan sehari-hari. Sebab hati yang bersih akan senantiasa mengajak taqarrub ila Allah. Seseorang yang hatinya senantiasa mendekat kepada Allah maka orang tersebut akan berada pada maqam keshalehan. Sebagaimana yang telah dijelaskan dalah sebuah hadits yang diriwayatkan oleh Bukhari Muslim, bahwa Nabi Muhammad bersabda, "Sesungguhnya Allah tidak melihat fisiologismu, tampangmu, melainkan Allah melihat hatimu," (HR. Bukhari Muslim).

Dari hadits tersebut di atas diketahui bahwa fisik dan tampang seseorang, baik yang panjang atau pendek, tampan atau jelek, kurus atau gemuk, putih atau hitam, tidak lain dan tidak bukan dari kesemua hal yang demikian itu dinilai adalah dari segi hatinya. Semakin bersih hati seseorang dari hal-hal yang tidak disenangi oleh Allah, maka semakin spesial kedudukannya di hadapan Allah SWT. Segala bentuk yang melekat pada diri manusia, tiada lain ialah pemberian dari Allah semua dan setiap pemberian Allah adalah sempurna. Hal ini dijelaskan pada Quran surat At-Tin ayat 4 yang memiliki arti "Sesunggubnya Kami telah menciptakan manusia dalam bentuk yang sempurna."
Begitu pun latar belakang seseorang, sebagaimana yang telah terurai di atas. Allah tidak pernah menilai orang tersebut berasal dari suku apa, wilayah, bahasa, dan identitas individu lainnya, akan tetapi Allah SW'T hanya menilai seorang hamba dari segi ketakwaannya semata. Sumber dari hal tersebut sebagaimana tertuang dalam Quran Surat Al-Hujarat ayat 13 dengan arti bahwa "Hai Manusia, sesunggubnya Kami telah menciptakan kamu dari seorang laki-laki dan perempuan, serta menjadikan kamu berbangsa-bangsa dan bersuku-suku supaya kamu saling mengenal di antara mereka. Sesunggubnya orang yang paling mulia di antara kamu di sisi Allah ialah orang yang paling bertakwa di antara kamu."

Jadi keterbatasan fisik pada Childreen Special Needs atau penyandang disabilitas tidak dapat mempengaruhi kedudukannya di sisi Allah. Sebab Allah tidak melihat seorang hamba dari aspek rupa, fisik, latar belakang, dan sebagainya, melainkan Allah SWT melihat dan menilai seorang hamba dari aspek ketakwaannya. Tidak ada perbedaan signifikan bagi semua umat manusia di dalam agama Islam, semuanya wajib dihormati dan memiliki derajat kemanusiaan yang sama.

\section{Pengertian dan Tipologi Disabilitas}

Disabilitas berasal dari kata bahasa Inggris yang berarti disability. Kata ini bisa disebut juga sebagai kata serapan yang direduksi ke dalam bahasa Indonesia. Secara khusus kata disability mempunyai pengertian (1) cacat; (2) ketidakmampuan. ${ }^{24}$ Cacat dapat dikategorikan sebagai cacat physical maupun cacat psychological. Sama halnya dengan cacat, ketidakmampuan juga dikategorikan secara physical ataupun psychological. Cacat dan ketidakmampuan menunjukkan adanya keterbatasan manusia yang menyandang disabilitas dalam melakukan suatu tindakan atau pekerjaannya dan partisipasinya. Adapun kata disabilities adalah bentuk jamak dari kata disability. ${ }^{25}$ Kedudukan disability adalah sebagai

\footnotetext{
${ }^{24}$ John M. Echols dan Hassan shadily, Kamus Inggris Indonesia, (Jakarta: PT Gramedia dan Ithaca London : Cornell University Press, 2003), 184.

25 John M. Echols dan Hassan shadily, Kamus Inggris Indonesia, (Jakarta: PT Gramedia dan Ithaca London : Cornell University Press, 2003), 184.
} 
noun (kata benda) ${ }^{26}$, bukan verb (kata kerja). Artinya yang cacat atau ketidakmampuannya itu bukan pada suatu pekerjaan, melainkan pada anggota physic ataupun psycisnya. Sedangkan keterbatasan dalam melakukan suatu aktivitas itu merupakan implikasi dari kecacatan physic maupun psycis yang diderita oleh penyandang disabilities.

Tidak jauh berbeda dengan arti kata dasarnya, dalam kamus ilmiah kata disabilitas memiliki arti (1) ketidakmampuan; (2) kecacatan; (3) ketidakcakapan. ${ }^{27}$ Sedangkan dalam KBBI kata disabilitas memiliki arti (1) keadaan (seperti sakit atau cidera) yang merusak atau membatasi kemampuan mental dan fisik seseorang; (2) keadaan tidak mampu melakukan hal-hal dengan cara yang biasa. Kedudukan kata disabilitas yang ada di KBBI ini mempunyai kesamaan dengan yang ada di an English-Indonesian Dictionary, yaitu sama-sama sebagai noun. Jadi, tidak ada perbedaan yang esensial mengenai interpretasi yang telah diuraikan di atas. Dalam Wikipedia, difabel atau disabilitas adalah istilah yang meliputi gangguan, keterbatasan aktivitas dan keterbatasan partisipasi. Permasalahan pada fungsi tubuh disebut gangguan, sedangkan kendala dalam melakukan aktivitas beserta keterbatasannya disebut sebagai keterbatasan aktivitas, adapun keterbatasan partisipasi berada pada aspek permasalahan seseorang atas partisipasinya disegala situasi dan kondisi kehidupan.

Penyandang disabilities bagi anak-anak ini juga disebut sebagai children special needs. Di mana anakanak yang memiliki keterbatasan atau mempunyai kebutuhan khusus. Sebagaimana yang telah dikutip oleh Dina Dwinita dalam jurnalnya dari apa yang telah dilansir oleh National Information Center for Children and Youth with Disabilities (NICHCY) menyatakan bahwa "children with special needs or special needs refer to children who have disabilities or who are at risk or developing disabilities". ${ }^{28}$

Ruang lingkup para penyandang difabel ini selalu dihadiri dengan rasa keterbatasan. Baik itu

\footnotetext{
${ }^{26}$ John M. Echols dan Hassan shadily, Kamus Inggris Indonesia, (Jakarta: PT Gramedia dan Ithaca London : Cornell University Press, 2003), 184.

${ }^{27}$ Pius Partanto dan M. Dahlan Albarry, Kamus Ilmiah Populer, (Surabaya: Arkola, 2001), 113.

${ }^{28}$ Dina Dwinita, "Pelaksanaan Bimbingan dan Konseling Anak Berkebutuhan Khusus", Jurnal Ilmiah Pendidikan Khusus, Vol. 1, No. 3, (Juli, 2018), 142.
}

berupa aktivitasnya dalam melakukan kegiatan seharihari atau pun keterbatasannya dalam menyampaikan aspirasi dan partisispasinya terhadap lingkungan sekitar atau pun sekelompok masyarakat tertentu. Oleh karena itu, kaum difabel ini perlu adanya perhatian khusus dari pihak yang berwajib. Supaya kaum difabel ini memiliki kesamaan derajat dengan manusia lainnya yang sehat jasmani maupun rohani.

Di sisi lain sebagai mitra pemerintah, sekolah harus mampu menciptakan sistem yang khusus bagi Children Special Needs. Dalam hal ini, bimbingan dan penyuluhan sangatlah dibutuhkan dalam mengawal perkembangan anak berkebutuhan khusus. Karena bimbingan dan penyuluhan menangani masalahmasalah atau hal-hal di luar bidang garapan pengajaran, akan tetapi secara tidak langsung menunjang tercapainya tujuan pendidikan dan pengajaran di sekolah. ${ }^{29}$ Tidak hanya itu, masyarakat setempat yang berada dekat dengan kehidupan kaum difabel haruslah membantu dalam megakomodasi segala sesuatu yang diperlukan kaum difabel ini. Sehingga pada nantinya kaum difabel tidak merasa dikucilkan atau direndahkan dalam keberadaannya di dunia dan bersama dunia. Terdapat relasi mutualisme yang baik antara manusia yang sehat jasmani maupun rohaninya dengan manusia penyandang disabilitas.

Interaksi yang komunikatif juga dapat tercipta bila manusia saling menghargai terhadap sesamanya dan tanggap dalam merespon dari lingkungannya. Manusia memliki enam indera sebagai saluran penerima data kasar dari lingkungannya, yaitu penglihatan (visual), pendengaran (audiotry), peradaban (tactile), kinestetik (knesthetic), penciuman (alfactory), dan pengecap (gustatory). ${ }^{30}$

Adapun spesifikasi dari tipologi disabiltas pada pembahasan ini ialah tertuju pada anak berkebutuhan khusus. Esensinya, seluruh anak akan tumbuh dan berkembang secara aktif dalam sebuah kepribadiannya yang utuh. Secara singkat, perkembangan (development) adalah proses atau tahapan pertumbuhan kearah lebih maju. Sedangkan pertumbuhan (growth) tahapan peningkatan sesuatu dalam hal jumlah ukuran dan arti pentingnya

\footnotetext{
${ }^{29}$ Wardati dan Mohammad Johar, Implementasi Bimbingan dan Konseling di Sekolah, (Jakarta: Prestasi Pustakarya, 2011), 54. ${ }^{30}$ Mulyono Abdurrahman, Pendidikan Bagi Anak Berkesulitan Belajar, (Jakarta: Asdi Mahasatya, 2003), 144.
} 
pertumbuhan juga bisa berarti sebuah tahapan perkembangan (a stage of development).

Namun di sisi lain, terdapat anak yang memiliki gangguan dalam pertumbuhan dan perkembangan kepribadiannya yang utuh. Anak tersebut tak lain dan tak bukan adalah anak yang berkebutuhan khusus atau Children Special Needs. Sebagaimana yang sedikit banyak telah dipaparkan sebelumnya. Perbedaan perkembangan yang lain di luar batas normal manusia pada umumnya merupakan sebuah gangguan yang harus mendapat perhatian lebih dari berbagai pihak guna dapat membantunya secara maksimal, akan sesuatu yang dibutuhkan oleh penyandang disabilitas.

Agar dapat membantu secara maksimal terhadap Children Special Needs, tentu dibutuhkan informasi-informasi atau segala keterangan menganai problem yang menjadi kebutuhannya. Termasuk juga mengenai tipologi Children Special Needs. Karena Children Special Needs ini mengalami permasalah khusus dalam belajar. Oleh karena itu, perlu penanganan khusus mengatasi kesulitan belajarnya. Beberapa kesulitan belajar di antaranya bersifat perkembangan (developmental learning disabilities) dan akademik (academic learning disabilities). ${ }^{31}$ Kesulitan belajar yang bersifat motorik tersebut mencakup keterampilan motorik, perseptual, bahasa, kognitif dan sosial. Berbagai kesulitan belajar ini telah dikuasai oleh anak yang tidak berkesulitan belajar sebelum masuk sekolah, tetapi bagi anak yang berkesulitan belajar memerlukan pengajaran secara sistematis. Orang tua dan guru perlu perlu bekerja sama dan membangun hubungan yang efektif antara keduanya. Orang tua dan guru yang bekerja bersama-sama bisa lebih efektif memilih hasrat untuk belajar di dalam diri sebagian besar murid. ${ }^{32}$

Gangguan perkembangan motorik anak sering terjadi sebab adanya gerakan melimpah atau overflow movements. Contoh ketika anak ingin menggerakkan tangan kanan ke atas, tangan kiri tanpa sengaja juga ikut bergerak ke atas. Anak yang tergolong di sini sering mengganggu kelas, karena tanpa sengaja menabrak kelas, jatuh dari kursi, pensil

\footnotetext{
${ }^{31}$ Mulyono Abdurrahman, Pendidikan Bagi Anak Berkesulitan Belajar, (Jakarta: Asdi Mahasatya, 2003), 143.

${ }^{32}$ Raymond J. Wlodkowski dan Judith H Jaynes, Eager To Learn, (Yogyakarta: Pustaka Pelajar, 2004), 40.
}

atau bukunya jatuh seketika dan memperlihatkan kecanggungan (clumsy). ${ }^{33}$

Terdapat strategi mengatasi anak yang tergolong dalam gangguan perkembangan motorik ini, di antaranya ialah dengan melempar, dapat dilakukan menggunakan bola berbagai ukuran yang diarahkan kepada guru atau anak-nak lain. Menangkap, dalam kegiatan ini tergolong lebih sulit dari pada melempar. Strategi selanjutnya adalah menggunting, bisa dimulai dari menggunting bendabenda atau sesuatu yang berpola lurus. Terakhir ialah melipat, bisa memulainya dengan melipat kertas menjadi seperti mainan perahu, pesawat terbang dan lain sebagainya. ${ }^{34}$

Children Special Needs ini memiliki klasifikasi secara permanen dan secara temporer. Children Special Needs atau anak berkebutuhan khusus permanen merupakan kasus di mana kelainan pada anak merupakan sesuatu yang bersifat tetap. Sesuai dengan makna katanya yaitu tetap; tahan; kekal; utuh; senantiasa. ${ }^{35}$ dan kemungkinan untuk berubahnya kecil. CSN permanen dapat dilihat pada anak yang menderita tunagrahita, tunanetra, tunawicara, tunalaras, tunaganda dan autis. ${ }^{36}$

Tunagrahita ditandai atau dialami oleh seorang anak yang memiliki keterbelakangan mental, juga kerap kali disebut sebagai retardasi mental (mental retardation). Pada umumnya anak penderita tunagrahita mengalami keterbatasan IQ jika dibandingkan dengan anak-anak yang lain, sehingga fungsi kecerdasan dan intelegensi mereka kerap terganggu di masa-masa perkembangannya yang berimplikasi pada munculnya permasalahan-permasalahan lain.

Tunanetra ialah seseorang yang mengalami masalah pada kondisi visualisasinya atau indera penglihatan. Terdapat dua jenis tunanetra berdasarkan kapasitasnya, yakni total blind dan low vision. Bagi penyandang tunanetra, indera-indera lain di luar

\footnotetext{
${ }^{33}$ Mulyono Abdurrahman, Pendidikan Bagi Anak Berkesulitan Belajar, (Jakarta: Asdi Mahasatya, 2003), 144.

${ }^{34}$ Mulyono Abdurrahman, Pendidikan Bagi Anak Berkesulitan Belajar, (Jakarta: Asdi Mahasatya, 2003), 160.

${ }^{35}$ Pius Partanto dan M. Dahlan Albarry, Kamus Ilmiab Populer, (Surabaya: Arkola, 2001), 589.

${ }^{36}$ Dina Dwinita, "Pelaksanaan Bimbingan dan Konseling Anak Berkebutuhan Khusus", Jurnal Ilmiah Pendidikan Khusus, Vol. 1, No. 3, (Juli, 2018), 144.
} 
indera penglihatan wajib diasah secara maksimal, semisal indera peraba, pencium, pendengar, dan lain sebagainya guna melengkapi kelemahan dari indera penglihat. Berkat upaya memaksimalkan indera-indera tersebut, tidak jarang ditemukan bahwa penyandang tunanetra memiliki bakat luar biasa seperti menyanyi, tari, atau ilmu pengetahuan.

Gangguan seseorang dalam kemampuannya di ranah verbal atau kendala berbicara disebut bisu. Ogan-organ yang dapat menyebabkan gangguan bisu pada biasanya terletak di organ-organ seperti lidah, paru-paru, mulut, tenggorokan, pita suara, dan lain sebagainya. Seorang anak yang terlahir bisu bisa disebabkan karena beberapa faktor, di antaranya ialah faktor genetika seperti keturunan, perkawinan antar kerabat yang terlalu dekat, seperti antara sepupu kandung, sehingga terjadi mutasi gen yang tidak wajar. Dalam statement lain juga disebut karena adanya infeksi pada ibu seperti cacar air selama kehamilan.

Anak yang mengalami bisu ini harus medapatkan pendekatan lebih. Karena jika tidak, akan berakibat pada penyimpangan bahasa. Terdapat empat tipe penyimpangan bahasa, anatara lain sebagai berikut:

1. Ketiadaan bahasa verbal, mungkin dikarenakan kegagalan saat kelahiran, kerusakan otak, atau masalah emosional yang parah.

2. Bahasa yang berbeda secara kualitatif, seperti hanya penggemaan yang ia katakan, yang disebabkan oleh kehilangan pendengaran, ketidak mampuan belajar, keterbelakangan mental atau masalah emosional.

3. Komunikasi verbal yang lambat, mungkin karena kehilangan pendengaran, model bahasa yang tidak memadahi, pengajaran orang tua yang buruk, kerusakan otak.

4. Bahasa yang diselingi, seringkali karena kehilangan pendengaran atau luka pada masa kanak-kanak akhir.

\section{Hak Penyandang Disabilitas untuk Memperoleh Bimbingan dan Penyuluhan}

Pendidikan pada saat ini menghadapi segala aspek dimensi kehidupan. Oleh karena itu, pendidikan bertujuan untuk mempersiapkan generasi muda menghadapi perubahan global yang sekarang telah dimulai. ${ }^{37}$ Dalam mempersiapkan hal tersebut, tentunya butuh sistem atau prinsip yang strategis dalam proses belajar siswa. Terdapat enam pilar yang direkomendasaikan oleh UNESCO sebagai prinsip pembelajaran yang bisa diterapkan dalam pendidikan secara global, yaitu learning to know, learning to do, learning to be, learning to live together, learning how to learn, learning troughout live..$^{38}$

Dalam proses belajar tentu tidak selamanya berjalan dengan lancar tanpa hambatan apapun. Melainkan terdapat rintangan yang bertubi-tubi dalam prosesnya. Sehingga dalam mengatasi rintangan tersebut dibutuhkanlah kehadiran seseorang guna membimbing, mengarahkan dan memberikan petunjuk terhadap jalan yang benar. Sesuai dengan kegiatan pendidikan yang bisa berupa bimbingan, pengajaran, atau latihan pendidikan selalu merupakan usaha yang direncanakan. ${ }^{39} \mathrm{Hal}$ ini diperkuat atas statement tentang tugas pendidik yang bukan hanya sekedar transfer of knowledge tapi dapat membimbing peserta didik dalam segala realitas yang dihadapinya dan menemukan ilmu pengetahuan secara mandiri. Sebagaimana yang telah dikatakan oleh Kandiri Masyrif dalam bukunya Psikologi Belajar, bahwa ilmu pengetahuan adalah kumpulan pengetahuan yang tersusun secara sistematis yang mempunyai metode-metode tertentu. ${ }^{40}$

Istilah bimbingan dan penyuluhan berasal dari kata bahasa Inggris "guidance and counseling." Kata guidance memiliki arti (1) bimbingan; (2) pedoman atau petunjuk. ${ }^{41}$ Dengan kedudukan katanya yaitu sebagai noun. Adapun verbnya adalah guide yang berarti (1) membimbing; (2) menuntun; (3) mempedomani. ${ }^{42}$

${ }^{37}$ H.A.R. Tilaar, Pedagogik Teoritis Untuk Indonesia, Jakarta: Kompas, 2015), 30.

${ }^{38}$ Moh. Nawafil, Cornerstone Of Education: Landasan-Landasan Pendidikan, (Yogyakarta: Absolut Media, 2018), 56.

${ }^{39}$ Abdul Kadir, Dasar-Dasar Pendidikan, Jakarta: Kencana, 2012), 61.

${ }^{40}$ Dewa Ketut Sukardi dan Nila Kesuma Wati, Proses Bimbingan dan Konseling Disekolah, (Jakarta: Rineka Cipta, 2008), 15.

${ }^{41}$ John M. Echols dan Hassan shadily, Kamus Inggris Indonesia, (Jakarta: PT Gramedia dan Ithaca London : Cornell University Press, 2003), 184.

${ }^{42}$ John M. Echols dan Hassan shadily, Kamus Inggris Indonesia, (Jakarta: PT Gramedia dan Ithaca London : Cornell University Press, 2003), 283. 
Counseling berasal dari kata dasar counsel yang berarti nasihat. ${ }^{43}$ Sedangkan counseling memiliki makna pemberi nasihat, penyuluhan.

Sedangkan dalam Kamus Lengkap Bahasa Indonesia, bimbingan berasal dari kata bimbing, yang memiliki arti tuntun, asuh, pimpin. ${ }^{44} \mathrm{Jadi}$, bimbingan secara sederhana dapat diartikan sebagai upaya membina atau membimbing sesuatu ke arah yang lebih baik. Bimbingan dan konseling adalah petunjuk atau penjelasan yang diberikan oleh yang ahli kepada seseorang dengan metode psikologis sehingga seseorang semakin memahami dirinya agar dapat menghadapi suatu masalah dengan baik. Bimbingan adalah suatu upaya sekolompok orang atau individu yang berperan sebagai pembimbing dalam rangka memberikan bantuan secara kontinuitas dan sistemik guna membentuk keperibadian objek yang dibimbing memiliki rasa kemandirian. ${ }^{45}$

Menurut James F Adams, counseling adalah suatu pertalian timbal balik antar dua orang yaitu (counselor yang membantu) dan (counselee yang dibantu) supaya dapat lebih baik memahami dirinya dalam hubungannya dengan masalah-masalah hidup yang dihadapinya pada waktu itu dan yang akan datang. Jadi konseling berperan bukan hanya pada masa saat ini saja, ketika dibutuhkan. Melainkan juga bisa bermanfaat pada masa yang akan datang. Saling bantu membantu dalam prosesnya, sudah nampak mengindikasikan tentang hakikat manusia sesungguhnya sebagai makhluk sosial. Adapun makhluk sosial yang dimaksud adalah makhluk sosial yang saling membutuhkan satu sama lain. Bukan malah sebagai makhluk yang individualistis.

Bimbingan konseling terhadap disabilitas atau anak berkebutuhan khusus (children special needs) adalah upaya yang berupa petunjuk dari seseorang ahli atau yang membantu (counselor) terhadap seseorang yang dibantu (counselee) dalam memahami kondisi dirinya dengan tujuan dapat menghadapi masalah dengan baik. Seseorang yang dibantu dalam konteks

\footnotetext{
${ }^{43}$ John M. Echols dan Hassan shadily, Kamus Inggris Indonesia, Jakarta: PT Gramedia dan Ithaca London : Cornell University Press, 2003), 150.

${ }^{44}$ Moh. Kusnadi, Kamus Lengkap Bahasa Indonesia, (Surabaya: Cahaya Agency, t.t), 92.

${ }^{45}$ Dewa Ketut Sukardi dan Nila Kesuma Wati, Proses Bimbingan dan Konseling Disekolah, Jakarta: Rineka Cipta, 2008), 6.
}

ini adalah anak yang berkebutuhan khusus atau penyandang disabilitas. Mengingat bahwa dalam Islam tidak ada perbedaan kasta di sisi Allah, kecuali berdasarkan amal ibadahnya. Setiap individu atau bagian dari society wajib mendapatkan hak atas pendidikan. Karena pendidikan memiliki muatan tujuan mendayagunakan segala potensi peserta didik bagi kehidupannya. Sebab itu pula dalam rangka mempersiapkan peserta didik yang kompeten, maka bimbingan, arahan, penyuluhan dari seorang guru sangatlah urgen terlebih kepada anak-anak berkebutuhan khusus.

Dari beberapa penjelasan di atas, dapat kita ketahui bersama bahwa eksistensi bimbingan dan konseling sangatlah diperlukan dalam dunia pendidikan khususnya diranah sekolah terhadap anak yang berkebutuhan khusus. Sebagai salah satu komponen penunjang pendidikan, bimbingan dan konseling mempunyai posisi kunci dalam kemajuan atau kemunduran pendidikan. Mutu pendidikan ikut ditentukan oleh bagaimana bimbingan dan konseling itu dimanfaatkan dan dioptimalkan fungsinya dalam pendidikan khususnya institusi sekolah. ${ }^{46}$

Sekolah haruslah bersifat welcome pada anak berkebutuhan khusus. Segenap perhatian haruslah dicurahkan pada anak ABK tersebut. Karena dengan hal itu, children special needs tidak akan dipandang sebelah mata oleh siapapun. Mereka sama-sama mempunyai hak dan kewajiban dalam hidup berbangsa dan bernegara di bumi pertiwi ini. Sesuai dengan apa yang diamanatkan oleh sila ke lima yaitu keadilan sosial bagi seluruh rakyat Indonesia. Seluruh rakyat Indonesia itu memiliki pengertian rakyat Indonesia secara universal. Tanpa ada unsur-unsur tertentu, baik berupa golongan, adat, budaya, ras, suku, miskin, kaya, agama, keturunan dan lain sebagainya.

Peran pemerintah dalam menyelenggarakan program pendidikan khusus juga sangat diperlukan dan diupayakan semaksimal mungkin. Karena pemerintah adalah pihak yang akan menjamin dan melindungi dalam proses kegiatannya. Dalam maknanya, pemerintah adalah kekuasaan memerintah sebuah negara, daerah, dan wilayah. ${ }^{47}$ Pada agenda

\footnotetext{
${ }^{46}$ Wardati dan Mohammad Johar, Implementasi Bimbingan dan Konseling di Sekolah, (Jakarta: Prestasi Pustakarya, 2011), 53. ${ }^{47}$ Moh. Kusnadi, Kamus Lengkap Bahasa Indonesia, (Surabaya: Cahaya Agency, t.t), 363.
} 
reformasi sistem pendidikan nasional pemerintah telah memberikan perhatian khusus bagi anak bangsa yang disebabkan oleh cacat atau kecerdasan luar biasa peserta didik. ${ }^{48} \mathrm{Hal}$ tersebut mengindakasikan pemerintah tidak main-main dalam mengatasi dan membimbing secara khusus children special needs dalam rangka sama-sama bisa mencapai keselamatan dan kebahagiaan setinggi-tingginya seperti halnya anak yang lain.

Hal di atas sesuai dengan definisi pendidikan yang diutarakan oleh bapak pendidikan Indonesia, yakni Ki Hajar Dewantara tentang pencapaian keselamatan dan kebahagiaan pendidikan yang setinggi-tingginya. Ia memberi definisi pendidikan sebagai tuntunan dalam hidup tumbuhnya anak-anak. Maksudnya, pendidikan menuntun segala kekuatan anak-anak itu agar mereka sebagai manusia dan anggota masyarakat dapatlah mencapai keselamatan dan kebahagiaan setinggi-tingginya. ${ }^{49}$ Bagaimanapun bentuk bimbingan pendidikan yang dilakukan di sekolah oleh yang ahli atau counselor tetap berpijak pada nilai-nilai pancasila sebagai dasar negara Indonesia. Selain itu, pancasila juga dijadikan sebagai dasar dalam pendidikan nasional.

Dalam setiap kegiatan atau aktivitas tertentu, pastilah manusia mempunyai tujuan. Karena tanpa memiliki tujuan, besar kemungkinan manusia tersebut mengalami gangguan dalam kejiwaannya. Dan yang membedakan antara manusia dan hewan adalah tujuan dalam aktivitas atau tindakannya. Oleh karena itu, Dalam setiap kegiatan yang disadari pelaksanaannya, memerlukan tujuan yang diharapkan. ${ }^{50}$

Tujuan bimbingan yang paling utama menurut Carl Rogers merupakan dari profesi membantu ialah termasuk pertumbuhan dan perkembangan psikologis terhadap kematangan sosial kliennya sendiri. Terdapat banyak kemiripan tujuan bimbingan dan penyuluhan terhadap Childreen Special Needs secara universal, namun demikian tujuan khas tetap harus ada dalam membimbing dan memberikan penyuluhan serta prosedur yang menjadi acuan. Kegiatan layanan

\footnotetext{
${ }^{48}$ Hasan Basri, Kapita Selekta Pendidikan, (Bandung: Pustaka Setia, 2012), 86.

${ }^{49}$ Abdul Kadir, Dasar-Dasar Pendidikan, Jakarta: Kencana, 2012), 61.

${ }^{50}$ Moh. Nawafil, Cornerstone Of Education: Landasan-Landasan Pendidikan, (Yogyakarta: Absolut Media, 2018), 93.
}

bimbingan dan konseling ABK seyogyanya dapat membatu anak berkebutuhan khusus ke luar dari persoalan pelik di ranah pemahaman diri, kesulitan belajar, perencanaan karir, beradaptasi di masyarakat dan mengatasi berbagai hambatan dalam dinamika kehidupannya secara mandiri. ${ }^{51}$ Selain itu tujuan bimbingan dan konseling yang utama dan paling utama adalah untuk mengenalkan peserta didik dalam hal ini children special needs menuju penghambaan secara totalitas kepada Allah SWT. Sebab dalam tujuan akhir pendidikan Islam ialah the complete submission to god on the level individual, community and humanity at large. ${ }^{52}$ Layanan bimbingan dan konseling terhadap disabiltas di ataranya adalah layanan individu, layanan bimbingan dan konseling kelompok, dan bimbingan karir.

1. Layanan Individu

Layanan individu terhadap anak berkebutuhan khusus mencakup layanan pribadi dan sosial yang berfungsi sebagai sarana Chil3reen Special Needs untuk dapat memiliki penerimaan diri, konsep diri yang baik dan adaptasi terhadap lingkungannya.

2. Layanan Bimbingan dan Konseling Kelompok

Layanan bimbingan kelompok dimaksudkan untuk memberikan bantuan kepada individu melalui kegiatan kelompok. ${ }^{53}$ Di dalam kegiatan tersebut terjadi beberapa dinamika yang menyeluruh bagi seluruh peserta layanan, sehingga pesan atau massage utama dari setiap materi layanan dapat ditangkap dengan baik oleh anak. ${ }^{54}$

\section{Bimbingan Karir}

Sebagai manusia yang utuh dan merdeka, Childreen Special Needs berhak mendapatkan bimbingan yang dapat menghantarkan diri pada kecakapan hidup. Artinya bimbingan dalam hal ini karir, sangat wajib diperoleh

\footnotetext{
${ }^{51}$ Juntika Nurihsan, Landasan Bimbingan dan Konseling, (Bandung: Remaja Rosdakarya, 2010), 13.

${ }^{52}$ Abuddin Nata, Ilmu Pendidikan Islam, Jakarta: Kencana, 2010), 8.

${ }^{53}$ Tohirin, Bimbingan dan Konseling Disekolah Madrasah: Berbasis Integrasi, (Jakarta: Rajawali Pers, 2009), 170.

${ }^{54}$ Mulyono Abdurrahman, Pendidikan Bagi Anak Berkesulitan Belajar, (Jakarta: Asdi Mahasatya, 2003), 2.
} 
bagi anak berkebutuhan khusus sebagai bekal memanfaatkan potensi dan bakat yang telah dikembangkan sebelumnya. Bimbingan karir dapat dipahami sebagai sebuah upaya untuk memberi arahan kepada ABK agar memahami potensi dirinya, mengetahui jenis-jenis karir yang tepat dan memahami konteks ruang lingkup dunia karir yang akan dijalani, hal ini berkaitan dengan proses adaptasi serta penyikapan terhadap hambatan-hambatan dalam berkarir. ${ }^{55}$

\section{SIMPULAN}

Sebagaimana yang dipaparkan oleh Abduddin Nata bahwa terdapat tiga landasan pendidikan, yaitu agama, filsafat dan ilmu pengetahuan. Landasan pendidikan berguna untuk perumusan konsep dan praksis pendidikan, khususnya pendiidkan Islam. Esensi dari pendidikan Islam itu sendiri ialah pada sebuah bimbingan fisiologis dan psikologis peserta didik untuk mempersiapkan kematangan dirinya guna menemukan potensi terbaik dan keperibadian luhur. Bimbingan yang diberikan oleh pendidik tertuju pada seluruh siswa tanpa terkecuali, termasuk Childreen Special Needs. Dalam agama Islam tidak ada perbedaan kedudukan manusia, entah itu anak disabilitas atau nondisabilitas, anak cerdas atau kurang pandai, dan lain sebagainya sebab Allah tidak melihat seorang hamba dari aspek rupa, fisik, latar belakang, dan sebagainya, melainkan Allah SWT melihat dan menilai seorang hamba dari aspek ketakwaannya. salah satu hak yang wajib diperoleh penyandang disabilitas dalam ranah bimbingan dan konseling yakni berupa layanan individu atau bimbingan karir.

\section{DAFTAR RUJUKAN}

Abdul Kadir, Dasar-Dasar Pendidikan, Jakarta: Kencana, 2012), 61.

Abdul Majid dan Yusuf Mudzakir, Ilmu Pendidikan Islam, (Jakarta: Prenada Media, 2006), 20.

Abuddin Nata, Ilmu Pendidikan Islam, (Jakarta: Kencana, 2010), 7.

Bimo Walgito, Bimbingan dan Konseling: Studi dan Karir, (Yogyakarta: Penerbit Andi, 2010), 201.

55 Bimo Walgito, Bimbingan dan Konseling: Studi dan Karir, (Yogyakarta: Penerbit Andi, 2010), 201.
Dewa Ketut Sukardi dan Nila Kesuma Wati, Proses Bimbingan dan Konseling Disekolah, (Jakarta: Rineka Cipta, 2008), 15.

Dina Dwinita, "Pelaksanaan Bimbingan dan Konseling Anak Berkebutuhan Khusus", Jurnal Ilmiah Pendidikan Khusus, Vol. 1, No. 3, (Juli, 2018), 144.

H.A.R. Tilaar, Pedagogik Teoritis Untuk Indonesia, (Jakarta: Kompas, 2015), 15.

Hans Wehr, A Dictionary of Modern Written Arabic, (Beirut: Librarie Du Liban and London: Macdonald and Evans LTD, 1974), 15.

Hasan Basri, Kapita Selekta Pendidikan, (Bandung: Pustaka Setia, 2012), 86.

Hasan Langgulung, Asas-Asas Pendidikan Islam, Jakarta: PT Al-Husana, 1988), 6-12

Jalaluddin dan Abdullah Idi, Filsafat Pendidikan: Manusia, Filsafat dan Pendidikan, (Depok: Raja Grafindo Persada, 2016), 72.

John M. Echols dan Hassan shadily, Kamus Inggris Indonesia, (Jakarta: PT Gramedia dan Ithaca London : Cornell University Press, 2003), 35.

Mahmud Yunus, Kamus Arab-Indonesia, (Jakarta: PT Hidakarya Agung, t.t), 278.

Moh. Kusnadi, Kamus Lengkap Bahasa Indonesia, (Surabaya: Cahaya Agency, t.t), 92.

Moh. Nawafil dan Junaidi, "Revitalisasi Paradigma Baru Dunia Pembelajaran yang Membaskan", Jurnal Pendidikan Islam Indonesia, vol. 4, No. 2, (April, 2020), 217-218.

Moh. Nawafil, Cornerstone Of Education: LandasanLandasan Pendidikan, (Yogyakarta: Absolut Media, 2018), 9-10.

Mulyono Abdurrahman, Pendidikan Bagi Anak Berkesulitan Belajar, (Jakarta: Asdi Mahasatya, 2003), 144.

Pius Partanto dan M. Dahlan Albarry, Kamus Imiah Populer, (Surabaya: Arkola, 2001), 589.

Raymond J. Wlodkowski dan Judith H Jaynes, Eager To Learn, (Yogyakarta: Pustaka Pelajar, 2004), 40.

Siti Murtiningsih, Pendidikan Sebagai Alat Perlawanan: 
Teori Pendidikan Radikal Paulo Freire, (Yogyakarta: Resist Book, 2004), 11.

Tohirin, Bimbingan dan Konseling Disekolah Madrasah: Berbasis Integrasi, (Jakarta: Rajawali Pers, 2009), 170.

Wardati dan Mohammad Johar, Implementasi Bimbingan dan Konseling di Sekolah, (Jakarta: Prestasi Pustakarya, 2011), 54. 